\title{
Effect of Frankincense (Boswellia thurifera) on Reproductive System in Adult Male Rat
}

\section{Mohamad Khalid Nusier, ${ }^{*, a}$ Hameed Nayef Bataineh, ${ }^{b}$ Ziad Mohydeen Bataineh, ${ }^{c}$ and Haytham Mahmoud Daradka ${ }^{d}$} ${ }^{a}$ Department of Biochemistry and Molecular Biology, ${ }^{b}$ Department of Physiology, ${ }^{c}$ Department of Anatomy, Jordan University of
Science and Technology, School of Medicine, Irbid 22110, Jordan, and d Department of Biology, Faculty of Science, Jarash University,
Jarash 21122, Jordan

(Received December 15, 2006; Accepted May 10, 2007)

\begin{abstract}
Ingestion of Frankincense [Boswellia thurifera (B. thurifera)] resin at a dose of 250 and $500 \mathrm{mg} / \mathrm{kg}$ body weight for 60 days by adult male rats was investigated for effects on fertility. Average weights of epididymis, ventral prostate and seminal vesicles increased significantly. Sperm motility and density were also significantly increased in cauda epididymis and in testes in Frankincense-treated groups. A significant increase of spermatogenesis in testes due to increase in the number of primary, secondary spermatocytes and spermatids in the treatment groups was attributed to a significant increase in testosterone and Follicle stimulating hormone (FSH). In addition, it also increased the number of implantations and the number of viable fetuses in female rats impregnated by these males, thereby increasing their fertility. The histometery of reproductive organs confirmed those results.
\end{abstract}

Key words — Frankincense, Boswellia thurifera, fertility, spermatogenesis, male rat, spermatids

\section{INTRODUCTION}

Fertility regulation with plant preparations has been reported in ancient literature of indigenous systems of medicine. A number of plant species have been tested for fertility regulation years ago and were subsequently fortified by national and international agencies. ${ }^{1-3)}$

Frankincense, also known as olibanum, is obtained from a scrubby tree of the genus Boswellia, native to the arid regions of Africa, India and the Middle East. The gum resin of Frankincense contains boswellic acids (BA) and other pentacyclic triterpenes, which have a chemical structure that closely resembles that of steroids. ${ }^{4)}$

It is commonly used in Indian system of medicine (Ayurvedic) as an anti-inflammatory, analgesic, anti-arthritic and anti-proliferative agent. In aromatherapy, Frankincense is valued for its effects on the respiratory system. It has been used in steam inhalations, baths and massages for catarrh, bronchitis and cough. Furthermore, it has been used as

\footnotetext{
*To whom correspondence should be addressed: Department of Biochemistry and Molecular Biology, Jordan University of Science and Technology, School of Medicine, Irbid 22110, Jordan. Tel.: +962-2-7201000 (ext. 23696); Fax: +962-2-7095010; Email: mick@just.edu.jo
}

antidote to hemlock. ${ }^{5)}$ Frankincense is also used for the treatment of tumors, ulcers, vomiting, dysentery and fever., ${ }^{6,7)}$ In china it is used for leprosy and leukemia. ${ }^{8-10)}$ This plant is currently used by Jordanian population as a phrodisiac and fertility promoting agent.

This work was conducted to examine the effect of Frankincense on the reproductive system and fertility in adult male rat.

\section{MATERIAL AND METHOD}

Animals and Treatment — Thirty adult male and 60 adult female Sprauge-Dawley rats 3 months old weighing approximately $300 \mathrm{gm}$ were bred in the Animal House Unit at Jordan University of Science and Technology, School of Medicine, between January and May 2005. Rats were maintained under controlled temperature of $21 \pm 1^{\circ} \mathrm{C}$ and $12 \mathrm{hr}$ light: $12 \mathrm{hr}$ darkness schedule. Food and water were available ad labitum.

Plant Material — Dried resin material [Boswellia thurifera (B. thurifera)] from plant was obtained from a local supplier. The material was dissolved in distilled water and administered orally to rats using animal feeding intubation needles (Pop- 
per and Sons, New York, NY, USA) in concentrations of 250 and $500 \mathrm{mg} / \mathrm{kg}$.

Determination of $\mathrm{LD}_{50}$ in mice was conducted to determine the dose to be given to rats. Graded doses of the aqueous extract of $B$. thurifera in 0.2 distilled water was administered intraperitonealy to six groups of six non fasted male albino mice (25$30 \mathrm{~g}$ each). They were housed in transparent plastic cages at $24^{\circ} \mathrm{C}$. Mortality was noted after $1 \mathrm{hr}{ }^{11,12)}$

Experimental Design — Male rats were divided into three groups: Control: This group received vehicle (distilled water) for 60 days and treatment groups 1 and 2, received Frankincense 250 and $500 \mathrm{mg} / \mathrm{kg}$ body weight for one reproductive cycle (60 days), respectively. After $24 \mathrm{hr}$ of the last dose, animals were weighed and autopsied under light ether anesthesia. Blood was collected through cardiac puncture using a dry and clean syringe, for serum studies.

Fertility Test — Fertility was estimated in both control and treatment groups. Each male rat was placed in an individual cage with two virgin untreated females of the same strain. Animals were left together for ten days during which two estrous cycles should have elapsed. ${ }^{13)}$ One week after the removal of the treated males, females were killed by cervical dislocation under light ether anesthesia and the number of pregnant females, number of implantation sites, number of viable fetuses and number of resorptions were recorded.

Sperm Motility and Count - To determine sperm motility and sperm counts, $100 \mathrm{mg}$ of cauda epididymides was minced in $2 \mathrm{ml}$ of physiological saline. One drop of evenly mixed sample was applied to a Neubauer's counting chamber under coverslip. Quantitative motility expressed as percentage was determined by counting both motile and immotile spermatozoa per unit area. Cauda epididymal and testicular sperm counts were performed by routine procedure and expressed as million $/ \mathrm{ml}^{14)}$

Body and Organ Weights — Initial and final body weights of animals were recorded. Reproductive tract was trimmed free of fat and each organ was weighed separately on electronic balance. The reproductive organs of males included testes, epididymides, ventral prostrate, seminal vesicle and vas deferens, were fixed in Bouin's fixative for histological studies.

Histological Studies — The Bouin's fixed reproductive organs were cut into small pieces and processed. The paraffin embedding was followed by section cutting $(5 \mu \mathrm{m})$ and staining (Harris Haema- toxyline and eosin. Sigma Aldrich, St Louis, Mo, USA).

Histometry — Using Camera Lucida, hundred circular appearing seminiferous tubules were traced at $\times 80$ and the diameter of each tubule was measured separately. The measurement was expressed as mean of all the traced tubules. Similarly, Leydig cell nuclei were traced at $\times 800$. The epithelial cell height of cauda epididymides, caput epididymides and seminal vesicle were also traced at $\times 360$.

Testicular Cell Population Counting — Spermatogenic elements i.e. spermatogonia, spermatocytes and spermatids were counted in $5 \mu \mathrm{m}$ thick cross sections of 10 seminiferous tubules in 10 animals of each group. All raw counts were transformed to "true" counts by an adaptation of Abercrombie formula ${ }^{15)}$ from germ cell diameter measurement.

Interstitial cell types (such as fibroblast, immature and mature Leydig cells and degenerating cells) were estimated, applying a differential count over 200 cells population and statistically verified by the binomial distribution. ${ }^{16)}$

Serum Biochemistry — Total protein, cholesterol, triglycerides, serum aspartate aminotranferase (AST), serum alanine aminotranferase (ALT) were measured using commercial kits from Cis BIO International (AST, ALT from CIS BIO International, Gif Sur Yvette, France)

Hormonal Assays — Plasma Follicle stimulating hormone (FSH) and testosterone concentrations were measured by radioimmunoassay using commercial kits from Cis BIO International.

Statistical Calculation - All the values of body/organ weight, biochemical estimation and histometry were expressed as mean value \pm S.D. The treatment groups were compared with the control group using chi-square test and Student's " $t$ " test. ${ }^{17)}$

\section{RESULTS}

\section{Effect of Frankincense (B. thurifera) on Body and Organ Weight}

Table 1 shows that intragastric administration of Frankincense (B. thurifera) caused an increase in body weight, when initial and final body weights were compared in treatment groups vs. control group. The relative weights of the testes, epididymides, seminalvesicle, ventral prostate and vas deferens were increased significantly. 
Table 1. Body and Organ Weights of Male Rat Ingested Frankincense (B. thurifera) Resin

\begin{tabular}{|c|c|c|c|c|c|c|c|}
\hline \multirow[t]{2}{*}{ Treatment } & \multicolumn{2}{|c|}{ Body weight (gm) } & Testes & Epididymides & Seminal vesicle & Ventral prostate & Vas deferens \\
\hline & Initial & Final & \multicolumn{5}{|c|}{$(\mathrm{mg} / 100 \mathrm{gm}$ body weight $)$} \\
\hline Control group & $308 \pm 2.80$ & $419 \pm 2.65$ & $875 \pm 25.21$ & $347 \pm 21.61$ & $376 \pm 14.38$ & $226 \pm 4.1$ & $65.8 \pm 4.36$ \\
\hline $\begin{array}{l}\text { Group } 1 \\
\text { B. thurifera } \\
(250 \mathrm{mg})\end{array}$ & $321 \pm 6.95$ & $444 \pm 10.87$ & $907^{*} \pm 21.8$ & $366^{*} \pm 16.33$ & $421^{*} \pm 11.03$ & $251^{*} \pm 4.11$ & $71.2 \pm 3.21$ \\
\hline $\begin{array}{l}\text { Group } 2 \\
\text { B. thurifera } \\
(500 \mathrm{mg})\end{array}$ & $310 \pm 8.31$ & $450 \pm 11.32$ & $914^{* *} \pm 19.36$ & $382^{* *} \pm 14.36$ & $447^{* *} \pm 12.69$ & $296^{* *} \pm 3.18$ & $76.8^{*} \pm 2.8$ \\
\hline
\end{tabular}

Table 2. Histometerical Parameters and Sperm Dynamics of Male Rat Ingested Frankincense (B. thurifera) Resin

\begin{tabular}{|c|c|c|c|c|}
\hline \multirow[t]{2}{*}{ Treatment } & \multirow[t]{2}{*}{$\begin{array}{l}\text { Sperm motility } \\
(\%)\end{array}$} & \multicolumn{2}{|c|}{$\begin{array}{l}\text { Sperm density } \\
(\text { million/ml) }\end{array}$} & \multirow{2}{*}{$\begin{array}{c}\text { Seminiferous tubule } \\
\text { diameter } \\
(\mu \mathrm{m})\end{array}$} \\
\hline & & \multicolumn{2}{|r|}{ epididymides } & \\
\hline Control group & $74.1 \pm 1.94$ & $4.75 \pm 0.47$ & $56.0 \quad \pm 0.94$ & $290.6 \pm 3.2$ \\
\hline Group $1 \quad$ B. thurifera $(250 \mathrm{mg})$ & $78.45^{*} \pm 2.21$ & $5.43^{*} \pm 0.14$ & $59.33 \pm 0.57$ & $296.84^{*} \pm 6.56$ \\
\hline Group 2 B. thurifera $(500 \mathrm{mg})$ & $83.26^{* *} \pm 1.08$ & $6.55^{* *} \pm 0.14$ & $61.185^{* *} \pm 0.88$ & $301.27^{* *} \pm 5.35$ \\
\hline \multirow[t]{2}{*}{ Treatment } & \multirow{2}{*}{$\begin{array}{l}\text { Leydig cell nuclear } \\
\text { diameter } \\
(\mu \mathrm{m})\end{array}$} & \multicolumn{3}{|c|}{$\begin{array}{l}\text { Epithelial cell height } \\
(\mu \mathrm{m})\end{array}$} \\
\hline & & $\begin{array}{c}\text { Cauda } \\
\text { epididymides }\end{array}$ & $\begin{array}{c}\text { Caput } \\
\text { epididymides } \\
\end{array}$ & $\begin{array}{l}\text { Seminal } \\
\text { vesicles }\end{array}$ \\
\hline Control group & $6.45 \pm 0.96$ & $38.8 \pm 0.32$ & $26.08 \pm 0.4$ & $17.32 \pm 0.17$ \\
\hline Group $1 \quad$ B. thurifera $(250 \mathrm{mg})$ & $7.47^{* *} \pm 1.13$ & $41.34^{*} \pm 2.68$ & $28.97^{* *} \pm 3.05$ & $23.7^{*} \quad \pm 0.27$ \\
\hline Group 2 B. thurifera $(500 \mathrm{mg})$ & $8.79^{* *} \pm 0.762$ & $44.68^{* *} \pm 2.68$ & $33.4^{* *} \pm 2.66$ & $28.45^{* *} \pm 0.27$ \\
\hline
\end{tabular}

Results are expressed as mean \pm S.D. Ten male rats were included per group. ${ }^{*} p<0.05,{ }^{* *} p<0.001$ significantly different from control group (Student's “ $t$ ” test).

Table 3. Testicular Cell Population Dynamics of Male Rat Ingested Frankincense (B. thurifera) Resin

\begin{tabular}{|c|c|c|c|c|}
\hline \multirow[t]{2}{*}{ Treatment } & \multicolumn{4}{|c|}{ Germinal cell types } \\
\hline & Spermatogonia & $\begin{array}{c}\text { Spermatocyte } \\
\text { (primary) }\end{array}$ & $\begin{array}{c}\text { Spermatocyte } \\
\text { (secondary) }\end{array}$ & Spermatids \\
\hline Control group & $23.99 \pm 0.93$ & $18.85 \pm 0.80$ & $64.126 \quad \pm 3.51$ & 147.71 \\
\hline Group $1 \quad B$. thurifera $(250 \mathrm{mg})$ & $24.75 \pm 5.33$ & $23.45^{*} \pm 2.66$ & \pm 4.86 & $165.77^{*} \quad \pm 7.33$ \\
\hline Group 2 B. thurifera $(500 \mathrm{mg})$ & $27.05^{*} \pm 4.44$ & $27.96^{* *} \pm 2.41$ & $97.97^{* * *} \pm 3.73$ & $189.32^{* * *} \pm 6.82$ \\
\hline \multirow[t]{2}{*}{ Treatment } & \multicolumn{4}{|c|}{ Interstitial cell type } \\
\hline & Fibroblast & $\begin{array}{c}\text { Immature } \\
\text { Leydig cell }\end{array}$ & $\begin{array}{c}\text { Mature } \\
\text { Leydig cell }\end{array}$ & $\begin{array}{l}\text { Degenerating } \\
\text { cell }\end{array}$ \\
\hline Control group & $63.83 \pm 1.64$ & $65.195 \quad \pm 3.47$ & $70.64 \quad \pm 1.03$ & \pm 1.67 \\
\hline Group $1 \quad$ B. thurifera $(250 \mathrm{mg})$ & $71.23^{* *} \pm 1.87$ & $74.90^{*}$ & $77.37^{*} \pm 1.16$ & \pm 1.44 \\
\hline B. thurifera $(500 \mathrm{mg})$ & $78.66^{* *} \pm 1.33$ & $81.66^{* *}$ & $86.66^{* * *} \pm 0.78$ & $13.0^{* *} \pm 0.76$ \\
\hline
\end{tabular}

Results are expressed as mean \pm S.D. Ten male rats were included per group. ${ }^{*} p<0.05,{ }^{* *} p<0.001,{ }^{* * *} p<0.001$ significantly different from control group (Student's " $t$ " test).

Effect of Frankincense (B. thurifera) on Sperm Dynamics and Histometrical Parameters

Sperm motility and density in cauda epididymis and testes, seminiferous tubule diameter and Leydig cell nuclear diameter and epithelial cell height in epididymides (cauda and caput) and seminal vesi- 
Table 4. Serum Biochemistry of Male Rat Ingested Frankincense (B. thurifera) Resin

\begin{tabular}{|c|c|c|c|c|c|c|c|c|}
\hline Treatment & $\begin{array}{l}\text { Glucose } \\
\text { (Mmol) }\end{array}$ & $\begin{array}{l}\text { Cholesterol } \\
\text { (Mmol) }\end{array}$ & $\begin{array}{l}\text { Triglycerides } \\
\text { (Mmol) }\end{array}$ & $\begin{array}{c}\text { Bilirubin } \\
(\mu \mathrm{mol})\end{array}$ & $\begin{array}{l}\text { AST } \\
\text { (U/L) }\end{array}$ & $\begin{array}{l}\text { ALT } \\
\text { (U/L) }\end{array}$ & $\begin{array}{l}\text { Testosterone } \\
(\mu \mathrm{mol} / \mathrm{l})\end{array}$ & $\begin{array}{c}\text { FSH } \\
\text { (IU/L) }\end{array}$ \\
\hline $\begin{array}{l}\text { Control } \\
\text { group }\end{array}$ & $5.95 \pm 0.37$ & $1.44 \pm 0.1$ & $0.69 \pm 0.18$ & $3.5 \pm 0.32$ & \pm 1.43 & \pm 4.12 & $13.92 \pm 2.53$ & $21.87 \pm 0.55$ \\
\hline $\begin{array}{l}\text { Group } 1 \\
\text { B. thurifera } \\
(250 \mathrm{mg})\end{array}$ & $6.45 \pm 0.87$ & $1.14 \pm 0.13$ & $0.64 \pm 0.37$ & $3.7 \pm 0.47$ & $65.54 \pm 2.90$ & $77.75^{* *} \pm 4.75$ & $15.65^{*} \pm 2.09$ & $25.78^{* *} \pm 2.39$ \\
\hline $\begin{array}{l}\text { Group } 2 \\
\text { B. thurifera } \\
(500 \mathrm{mg})\end{array}$ & $7.76 \pm 0.49$ & $0.88^{*} \pm 0.06$ & $0.55^{*} \pm 0.65$ & $3.8 \pm 0.37$ & $53.11^{*} \pm 2.11$ & $73.55^{*} \pm 5.66$ & $18.83^{* *} \pm 1.89$ & $30.64^{* *} \pm 1.65$ \\
\hline
\end{tabular}

Results are expressed as mean \pm S.D. Ten male rats were included per group. ${ }^{*} p<0.05,{ }^{* *} p<0.001$ significantly different from control group (Student's " $t$ " test).

Table 5. Effect of Frankincense (B. thurifera) Resin Ingestion on Fertility in Adult Male Rats

\begin{tabular}{lccccc}
\hline \hline Treatment & $\begin{array}{c}\text { No. of } \\
\text { female }\end{array}$ & $\begin{array}{c}\text { No. of pregnant } \\
\text { females }\end{array}$ & $\begin{array}{c}\text { No. of implantation } \\
\text { sites }\end{array}$ & $\begin{array}{c}\text { No. of viable } \\
\text { fetuses }\end{array}$ & $\begin{array}{c}\text { No. of resorption/ } \\
\text { total no. of implantation }\end{array}$ \\
\hline Control group & 20 & $16 / 20(80 \%)$ & $9.62 \pm 1.66$ & $8.28 \pm 1.16$ & $7 / 133(5.26 \%)$ \\
Group 1 & 20 & $17 / 20(85 \%)$ & $10.55^{*} \pm 1.31$ & $9.67^{*} \pm 1.54$ & $5 / 164(3.05 \%)$ \\
$\begin{array}{l}\text { B. thurifera }(250 \mathrm{mg}) \\
\text { Group 2 }\end{array}$ & 20 & $19 / 20(95 \%)$ & $11.37^{* *} \pm 1.31$ & $10.83^{* *} \pm 1.54$ & $3 / 197(1.45 \%)$ \\
B. thurifera $(500 \mathrm{mg})$ & & & & & \\
\hline
\end{tabular}

Results are expressed as mean \pm S.D. Ten male rats were included per group. ${ }^{*} p<0.05,{ }^{* *} p<0.001,{ }^{* * *} p<0.001$ significantly different
from control group (Student's " $t$ " test).

cle were significantly increased in treated animals in comparison with controls (Table 2).

\section{Effect of Frankincense (B. thurifera) on Testicu- lar Cell Population Dynamics}

Administration of Frankincense (B. thurifera) resin solution caused a significant increase in the germinal cell population; spermatogonia, primary and secondary spermatocytes and spermatids. Immature and mature Leydig cells number were also significantly increased. However, degenerating cells number was decreased (Table 3 ).

\section{Effect of Frankincense (B. thurifera) on Bio- chemical Changes Analysis}

Table 4 demonstrates a significant increase in the serum level of glucose. Conversely, a significant reduction in total cholesterol and triglyceride levels, AST and ALT, the levels of plasma FSH and testosterone is noted in the treatment groups as compared to the control group.

\section{Effect of Frankincense (B. thurifera) on Male Rat Fertility}

The number of females impregnated by treated male rats was increased. Moreover, the num- ber of implantations and number of viable fetuses were also significantly increased in those females (Table 5).

\section{DISCUSSION}

Frankincense (B. thurifera) resin is widely used by Jordanian population as a phrodisiac and fertility promoting agent. The animal model used in this work has been previously used by several researchers to assess the effect of various extracts obtained from medicinal plants on reproductive functions in male. ${ }^{18-20)}$ Spermatogenic process in rats requires 53 days out which spermatozoa spend the last 6 to 7 days in the final transit through epididymides. ${ }^{21,22)}$ Frankincense was administrated for one complete spermatogenic cycle.

Present investigation demonstrates that oral administration of $B$. thurifera promoted increased fertility in male albino rats. The weight of reproductive organs was markedly increased (Table 1). The weight, size and secretory function of testes, epididymes, seminal vesicles, ventral prostate and vasa deferentia are closely regulated by androgens. ${ }^{23,24)}$ The drug may act on pituitary gland and increase 
main hormones of spermatogenesis. The process of spermatogenesis and accessory reproductive organs function are androgen dependent. Increased androgen production is reflected in an increase number of mature Leydig cells and their functional status. In this study the number of degenerating Leydig cells were significantly decreased, it reflects the increase of androgen level. This was further confirmed by increased number of spermatocytes (primary and secondary) and spermatids as these stages are completely androgen dependent. ${ }^{25-27)}$ The increased weight and histometry of reproductive organs further prove androgen increase. Significant increase in sperm motility of cauda epididymis was observed in treatment groups. This might be due to the effect of Frankincense (B. thurifera) on the enzymes of oxidative phosphorylation.

The results presented in this work also show that ingestion Frankincense (B. thurifera) by adult male rats increased the number of females impregnated by the exposed males (Table 5). Additionally, the number of implantations and the number of viable fetuses were also increased, which may possibly be due to the increase in sperm motility and sperm density.

In conclusion Frankincense (B. thurifera) resin ingestion possesses strong compound effect on fertility, mainly by affecting pituitary gland cells. Further studies are in progress to identify the precise mode of action of Frankincense.

Acknowledgements This work was supported by the Deanship of Scientific Research at Jordan University of Science and Technology, School of Medicine, grant No (171/2005).

\section{REFERENCES}

1) Sinha, R. (1990) Post-testicular antifertility effects of Abrus precatorius seed extract in albino rats. $J$. Ethnopharmacol, 28, 173-181.

2) Dixit, V. P., Gupta, R. S. and Gupta, S. (1989) Antifertility plant products: testicular cell population dynamicsfollowing solasodine (C27H43O2N) administration in rhesus monkey (Macaca mulatta). Andrologia, 21, 542-546.

3) Purohit, A. and Daradka, H. M. M. (1999) Antiandrogenic efficacy of Curcuma longa (50\% EtOH extract) with special emphasis on testicular cell population dynamics. Indian Drugs, 36, 142-143.

4) Syrovets, T., Buchele, B., Gedig, E., Slupsky, J. R. and Simmet, T. (2000) Acetyl-boswellic acids are novel catalytic inhibitors of human topoisomerases I and II alpha. Mol. Pharmacol., 58, 71-81.

5) Pandey, R. S., Singh, B. K. and Tripathi, Y. B. (2005) Extract of gum resins of Boswellia serrata L. inhibits lipopolysaccharide induced nitric oxide production in rat macrophages along with hypolipidemic property. Indian J. Exp. Biol., 43, 509-516.

6) Michie, C. A. and Cooper, E. (1991) Frankincense and myrrh as remedies in children. J. R. Soc. Med., 84, 602-605.

7) Hillson, R. M. (1988) Gold, frankincense and myrrh. J. R. Soc. Med., 81, 542-543.

8) Zhao, W., Entschladen, F., Liu, H., Niggemann, B., Fang, Q., Zaenker, K. S. and Han, R. (2003) Boswellic acid acetate induces differentiation and apoptosis in highly metastatic melanoma and fibrosarcoma cells. Cancer Detect. Prev., 27, 67-75.

9) Hostanska, K., Daum, G. and Saller, R. (2002) Cytostatic and apoptosis-inducing activity of boswellic acids toward malignant cell lines in vitro. Anticancer Res., 22, 2853-2862.

10) Jing, Y., Nakajo, S., Xia, L., Nakaya, K., Fang, Q., Waxman, S., Han, R. (1999) Boswellic acid acetate induces differentiation and apoptosis in leukemia cell lines. Leuk. Res., 23, 43-50.

11) Hruskova, J. Danes, L. and Kliment, V. (1961) Venezuelan equine encephalomyelitis virus: determination of inhalation LD50 for guinea pigs and mice. Acta Virol., 13, 203-208.

12) Litchfield, J. T. and Wilcoxon, F. A. (1970) A simplified method of evaluating dose-effect experiments. J. Pharmacol. Exp. Ther., 96, 99-113 [Ipstein, J. and Poly, F. (1949) Banchroft's introduction to biostatics, II Ed., Harper international, Epstein J. New York, NY, p.44.]

13) Bronson, F. H. (1979) The reproductive ecology of the house mouse. Q. Rev. Biol., 54, 265-299.

14) Prasad, M. R., Chinoy, N. J. and Kadam, K. M. (1972) Changes in succinic dehydrogenase levels in the rat epididymis under normal and altered physiologic conditions. Fertil. Steril., 23, 186-190.

15) Abercrombie, M. (1946) Estimation of nuclear population from microtome section. Anat. Rec., 94, 238-248.

16) Dixon, W. and Massey, F. J. (1957) Introduction of statistical analysis. McGRaw Hill Book Co. ubs., New York, p.228.

17) Ipstein, J. and Poly, F. (1970) Banchroft's introduction to biostatics, II Ed., Harper international, Harper international New York, NY, pp.44-64.

18) Al-Dissi, N. M., Salhab, A. S. and Al-Hajj, H. A. (2001) Effects of Inula viscosa leaf extracts on abor- 
tion and implantation in rats. J. Ethnopharmacol., 77, 117-121.

19) Pakrashi, A. and Pakrashi, P. L. (1977) Interceptive \& abortifacient activity of Aristolochia indica L. \& possible mode of action. Indian J. Exp. Biol., 15, 428-430.

20) Lohiya, N. K., Goyal, R. B., Jayaprakash, D., Ansari, A. S. and Sharma, S. (1994) Antifertility effects of aqueous extract of Carica papaya seeds in male rats. Planta Med., 60, 400-404.

21) Wang, L., Ye, W., Liu, X. and Guo, Y. (2000) Combined use of steroid hormone and low dose gossypol for antifertility and its mechanism in rats. Zhongguo Yi Xие Ke Xиe Yuan Xиe Bao., 22, 214-219.

22) Ke, Y. B. and Tso, W. W. (1982) Variations of Gossypol susceptibility in rat spermatozoa during spermatogenesis. Int. J. Fertil., 27, 42-46.

23) Juan, M. E., Gonzalez-Pons, E., Munuera, T., Ballester, J., Rodriguez-Gil, J. E. and Planas, J. M. (2005) trans-Resveratrol, a natural antioxidant from grapes, increases sperm output in healthy rats. $J$. Nutr., 135, 757-760.

24) Khan, U. A., Aslam, M. and Saeed, S. A. (2004) Effect of beta adrenergic antagonist on the production of testosterone by rat's Leydig cells. J. Ayub. Med. Coll. Abbottabad., 16, 26-28.

25) Aleem, M., Choudhari, J., Padwal, V., Balasinor, N., Parte, P. and Gill-Sharma, M. K. (2005) Hyperprolactinemia affects spermiogenesis in adult male rats. J. Endocrinol. Invest., 28, 39-48.

26) Sriraman, V., Sairam, M. R. and Jagannadha, R. A. (2004) Evaluation of relative role of $\mathrm{LH}$ and FSH in restoration of spermatogenesis using ethanedimethylsulphonate-treated adult rats. $R e$ prod. Biomed. Online., 8, 167-174.

27) Hossaini, A., Dalgaard, M., Vinggaard, A. M., Pakarinen, P. and Larsen, J. J. (2003) Male reproductive effects of octylphenol and estradiol in Fischer and Wistar rats. Reprod. Toxicol., 17, 607-615. 